Pemodelan 3D Data ...

\title{
PEMODELAN 3D DATA GAYA BERAT UNTUK MENGIDENTIFIKASI SUMBER PANAS DAERAH PANAS BUMI SIPOHOLON, SUMATERA UTARA
}

\author{
Jobit Parapat ${ }^{1)}$, Anik Hilyah ${ }^{1)}$, Widya Utama'), Tony Rahadinata ${ }^{2)}$ \\ ${ }^{1}$ Teknik Geofisika, Fakultas Teknik Sipil, Lingkungan dan Kebumian, Institut Teknologi Sepuluh Nopember Surabaya, \\ ${ }^{2}$ Pusat Sumber Daya Mineral Batubara dan Panas Bumi, Badan Geologi \\ e-mail : jobit.parapat@gmail.com
}

\begin{abstract}
Abstrak. Daerah Sipoholon, yang terletak di Kabupaten Tapanuli Utara, berdasarkan manifestasi permukaan dan pola geologinya merupakan daerah yang berpotensi adanya sumber daya panas bumi. Potensi ini belum dikembangkan untuk keperluan pembangkit listrik karena belum adanya model konseptual, informasi sistem kerja, dan jenis sumber panas di daerah ini. Survei gaya berat telah dilakukan di daerah ini pada tahun 2005. Terdapat 230 data gaya berat telah diukur di daerah ini dengan cakupan luas pengukuran sekitar $14 \mathrm{~km}$ x $16 \mathrm{~km}$. Oleh karena itu, penulis telah melakukan pemodelan 3D pada data gaya berat tersebut untuk mengidentifikasi sumber panas daerah penelitian berdasarkan distribusi densitas batuan secara tiga dimensi (3D). Pemodelan ini memanfaatkan teknik inversi 3D menggunakan perangkat lunak Grablox yang menggabungkan 2 metode inversi yaitu inversi singular value decomposition (SVD) dan inversi Occam. Hasil pemodelan ini memperlihatkan bahwa adanya blok batuan berdensitas tinggi dengan nilai antara $2,80-3,00 \mathrm{~g} / \mathrm{cm}^{3}$ yang berada di bagian selatan dan timur dengan kedalaman $>2 \mathrm{~km}$. Blok batuan ini diinterpretasikan sebagai tubuh batuan beku intrusi dan diduga berperan sebagai sumber panas dari sistem panas bumi Sipoholon. Hasil penelitian ini dapat digunakan sebagai informasi awal dalam pembuatan model konsptual sistem panas bumi daerah Sipoholon.
\end{abstract}

Kata kunci : Densitas, gaya berat, model konseptual, pemodelan inversi 3D, sumber panas

\begin{abstract}
Abstact. Sipoholon area, based on its surface manifestations and geological setting, is a potential area of geothermal resource. Unfortunately, this potential has not been developed for power plant purpose, because the absence of conceptual model, information of working system, and type of heat source of this area. At 2005, series of gravity investigation has been done in this field. The gravity data were measured from 230 stations covering an area of about $16 \mathrm{~km} \times 14 \mathrm{~km}$. Therefore, the author has done $3 D$ modeling of the same gravity data to identify the heat source of this area based on 3D model of density distribution. This modeling use 3D inversion method of Grablox software which combine 2 (two) inversion method namely singular value decomposition (SVD) and Occam inversion. The result of this modeling show that there is a presence of high density blocks whose value between $2,80-3,00 \mathrm{~g} / \mathrm{cm}^{3}$ which located in the southern and eastern with $>2 \mathrm{~km}$ of depth. These blocks is interpreted as an intrusive body and considered as the heat source of Sipoholon geothermal system. The result of this study can be used as an initial information in making conceptual model of geothermal system of this area.
\end{abstract}

Keywords : 3D inversion modeling, conceptual model, density, gravity, heat source

\section{PENDAHULUAN}

Daerah Sipoholon, yang terletak di Kabupaten Tapanuli Utara, berdasarkan manifestasi permukaan panas bumi dan pola geologinya merupakan daerah yang berpotensi adanya sumber daya panas bumi. Namun, potensi belum dikembangkan untuk keperluan pembangkit tenaga listrik (Situmorang, 2005), karena belum adanya model konseptual sistem panas bumi daerah. Model konseptual adalah penggabungan model deskriptif maupun kualitatif yang menyatukan informasi fisik penting dari sistem panas bumi (Zarkasyi, 2015). Model ini dihasilkan dari integrasi hasil penelitian geologi, geokimia, dan geofisika.

Daerah panas bumi Sipoholon sudah pernah diteliti dari segi geologi, geokimia, dan geofisika pada tahun 2005. Salah satu metode geofisika yang digunakan dalam penyelidikan potensi panas bumi di daerah Sipoholon ini adalah metode gaya berat. Penggunaan metode ini dalam eksplorasi panas bumi cukup efektif karena dapat mendelineasi struktur bawah permukaan (Atef, 2016) berupa 
indikasi sumber panas yang ditandai dengan kontras densitas tinggi (Sugianto, 2015). Hasil dari pengukuran ini perlu dimodelkan untuk mendapatkan persebaran densitas bawah permukaannya. Pemodelan gaya berat terdahulu yang pernah dilakukan di daerah ini masih menggunakan teknik pemodelan kedepan dua dimensi (Djudjun, 2005) sehingga belum sepenuhnya menggambarkan kondisi bawah permukaannya. Selain itu, hasil penelitian geologi, geofisika, dan geokimia sebelumnya belum menunjukkan jenis sumber panas daerah penelitian, sehingga sampai saat ini sistem kerja panas bumi daerah ini masih dalam perdebatan. Oleh karena itu, untuk melengkapi informasi tersebut, perlu adanya pemodelan inversi secara tiga dimensi (3D inversion modeling) terhadap data gaya berat yang sama, sehingga dihasilkan informasi bawah permukaan yang lebih akurat khususnya indikasi sumber panas dari sistem panas bumi daerah Sipoholon ini. Hasil dari studi ini dapat digunakan sebagai informasi awal dalam pembuatan model konseptual sistem panas bumi daerah penelitian.

Lokasi daerah penelitian ini adalah daerah panas bumi Sipoholon yang secara administratif terletak di Kecamatan Sipoholon bagian tenggara dan Kecamantan Tarutung bagian utara, Kabupaten Tapanuli Utara, Provinsi Sumatera Utara. Daerah ini berjarak sekitar $280 \mathrm{~km}$ sebelah selatan Kota Medan dengan jarak tempuh 7 jam melalui jalur darat. Secara geografis, daerah ini terletak antara

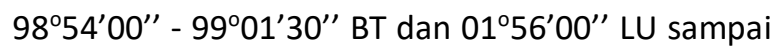
02 $06^{\prime} 00^{\prime \prime}$ LU atau antara $488000 \mathrm{mT}$ - $504000 \mathrm{mT}$ dan 215600 - $232100 \mathrm{mU}$ pada sistem koordinat UTM zona 47 belahan bumi utara.

Lokasi penelitian ini merupakan salah satu daerah berpotensi panas bumi yang sudah ditetapkan menjadi Wilayah Kerja Pertambangan (WKP) oleh Kementerian Energi dan Sumber Daya Energi Republik Indonesia. Namun sampai saat ini belum dimanfaatkan secara tidak langsung untuk pembangkit listrik. Hal ini diakibatkan karena masih perlunya penelitian lain yang lebih rinci untuk memastikan model konseptual sistem panas bumi daerah ini dan besarnya potensi energi yang bisa dibangkitkan. Daerah penyelidikan memiliki ukuran sekitar 14 km (ke arah timur) x 16 km (ke arah utara).

\section{METODOLOGI}

Data yang digunakan dalam penelitian ini adalah data hasil pengukuran metode gaya berat. Data gaya berat dihasilkan dari 230 titik stasiun pengukuran, dimana 7 lintasan berarah barat-timur (177 stasiun teratur) dan titik regional (53 stasiun acak) dengan spasi $250 \mathrm{~m}$ hingga $500 \mathrm{~m}$, yang tersebar di sekitar graben Tarutung. Data yang didapatkan kemudian direduksi dengan beberapa koreksi yang umum, termasuk koreksi medan (terrain), sehingga dihasilkan data anomali Bouguer. Kemudian data anomali Bouguer dipisahkan menggunakan metode second vertical derivative (SVD) dengan aplikasi filter Elkins, sehingga dihasilkan anomali residual (Gambar 1).

Pada penelitian ini, pemisahan anomali dilakukan menggunakan filter Second Vertical Derivative (SVD) pada perangkat lunak Surfer 11 dengan mengaplikasikan operator filter Elkins (Elkins, 1951). Dari proses pemisahan ini, output (keluaran) yang dihasilkan adalah data anomali residual. Kemudian anomali residual ini dimodelkan secara inversi untuk menghasilkan model sebaran densitas bawah permukaan daerah penelitian.

Pemodelan struktur bawah permukaan ini dilakukan dengan teknik inversi tiga dimensi (3D). Inversi 3D ini dilakukan dengan menggunakan perangkat lunak Grablox 1.6 dari Pirttijarvi (2004) sehingga menghasilkan model pe nampang densitas berbentuk 3D. Perangkat lunak ini menggabungkan dua metode inversi yaitu inversi Singular Value Decomposition (SVD) dan inversi Occam (Hjelt, 1992) yang diproses secara berurutan.

Inversi Singular Value Decomposition adalah suatu teknik penguraian suatu matriks ke dalam dua matriks (Zhao, 2011), sebagai contoh dari matriks A menjadi matriks $U$ dan V. Secara matematis persamaannya (Sugianto, 2015) dapat ditulis sebagai:

$$
A=U S V^{T}
$$

dengan: 
$U$ : matriks ortogonal sebelah kiri

$S$ : matriks diagonal

$V$ : matriks ortogonal sebelah kanan

$T$ : transpose matriks

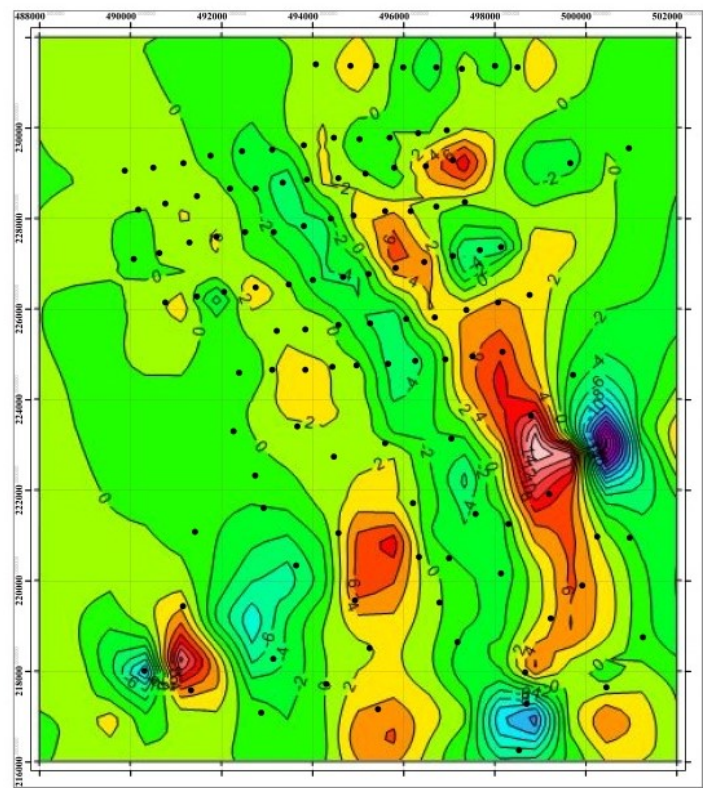

Gambar 1. Peta anomali residual

Inversi Occam adalah suatu metode inversi yang memanfaatkan tingkat kekasaran model (Constable, 1987). Metode ini sering diaplikasikan pada pengolahan data Magnetotelurik (Budiraharjo et al., 2017; Wijaya et al., 2016) yang secara matematis dapat ditulis:

$$
U=|| ð m /\left.\right|^{2}+\mu^{-1}\left\{|| W d-W G m||^{2}-X^{2}\right\}
$$

dengan:

$$
\begin{array}{ll}
\| \text { } / \text { Jm } /\left.\right|^{2} & : \text { kekasaran (roughness) } \\
\mu & : \text { Lagrange multiplier } \\
/ / W d-W G m /\left.\right|^{2} & : \text { misfit } \\
\mathrm{X} & : \text { error }
\end{array}
$$

Pemodelan inversi ini biasanya bersifat tidak unik atau tidak tunggal (Grandis, 2009), artinya suatu respon anomali bisa dihasilkan oleh beberapa model bawah permukaan. Oleh karena itu, salah satu solusinya adalah penggunaan kedua metode inversi tersebut diatas. Integrasi kedua metode inversi tersebut mampu mengurangi dan menghasilkan nilai error (antara data observasi dengan data hasil perhitungan) yang lebih kecil, baik dari sisi nilai densitas maupun dimensinya melalui proses optimize, sehingga dihasilkan model densitas yang lebih akurat.

\section{HASIL DAN PEMBAHASAN}

Model awal (Gambar 2) dibuat menggunakan perangkat lunak Grablox 1.6 dimana sumbu $X$ dibagi menjadi 28 blok ( $\mathrm{nx}$ ), sumbu $\mathrm{Y}$ menjadi 32 blok (ny), dan sumbu Z menjadi 10 blok (nz) sehingga menghasilkan 8960 blok minor. Data anomali residual kemudian diinversikan terhadap model awal. Proses inversi dilakukan dengan beberapa tahapan optimasi yaitu optimasi dasar (Base), densitas (Density), Occam densitas (Occam d), ketinggian blok (Heights) dan Occam ketinggian blok (Occam h). Hasil akhir dari proses inversi akan menghasilkan model densitas tiga dimensi (3D).
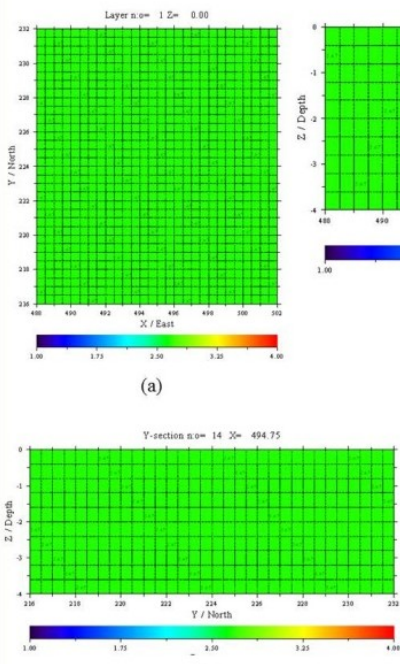

(c)

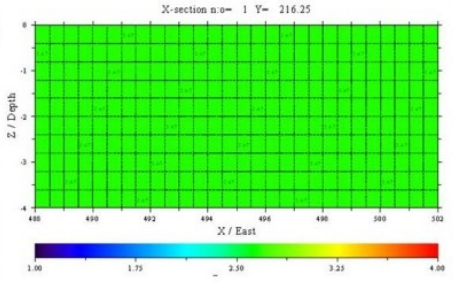

(b)

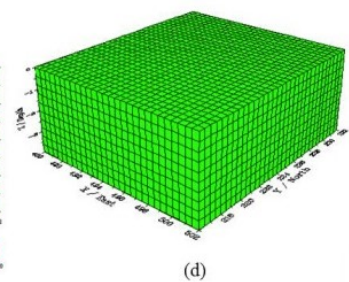

(d)
Gambar 2. Model awal yang digunakan

Hasil pemodelan 3D kemudian ditampilkan dalam bentuk sayatan penampang densitas 2D. Penampang model tersebut merupakan gambaran densitas batuan secara vertikal hasil sayatan model 3D. Pada penelitian ini, disajikan 6 (enam) penampang sayatan 2D dengan lintasan berarah barat-timur karena mempertimbangkan struktur geologi berupa sesar yang ada sebagai pengontrol 
kemunculan manifestasi mata air panas di daerah penelitian.

Penampang model 2D lintasan 1 yang terdapat pada $Y=216,75$ ditunjukkan oleh Gambar 3. Berdasarkan pada peta geologi daerah panas bumi Sipoholon, sayatan penampang ini melintasi daerah Gunung Martimbang, satuan piroklastik Toba 1, satuan piroklastik Toba 2, dan juga Gunung Jorbing. Sayatan ini merupakan sayatan paling selatan dari daerah penelitian. Anomali maksimal pada sayatan ini bernilai sekitar 5 mgal. Kondisi ini dikarenakan oleh adanya massa batuan berdensitas tinggi (warna merah) dengan nilai $2,85-3,00 \mathrm{~g} / \mathrm{cm}^{3}$ pada koordinat $X$ antara 492 sampai 497 dan mulai pada kedalaman $Z>1 \mathrm{~km}$.

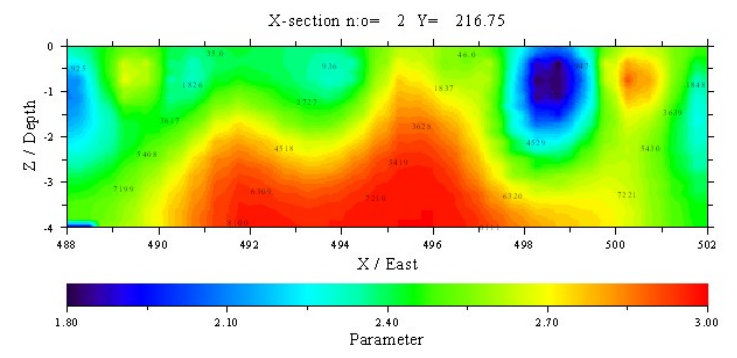

Gambar 3. Penampang model 2D lintasan 1

Penampang model $2 \mathrm{D}$ lintasan 2 yang terdapat pada $Y=219,75$ ditunjukkan oleh Gambar 4. Berdasarkan pada peta geologi daerah panas bumi Sipoholon, sayatan penampang ini melintasi daerah mata air panas Parbubu, satuan endapan aluvium, sinter karbonat, satuan piroklastik Toba 2, dan juga Gunung Jorbing. Anomali maksimal pada sayatan ini bernilai sekitar 8 mgal. Kondisi ini dikarenakan oleh adanya massa batuan berdensitas sedang (warna jingga) dengan nilai $2,75-2,90 \mathrm{~g} / \mathrm{cm}^{3}$ yang tersebar dibawah permukaan membentuk pola penerobosan keatas dengan rata-rata pada kedalaman 1 - 1,5 km.

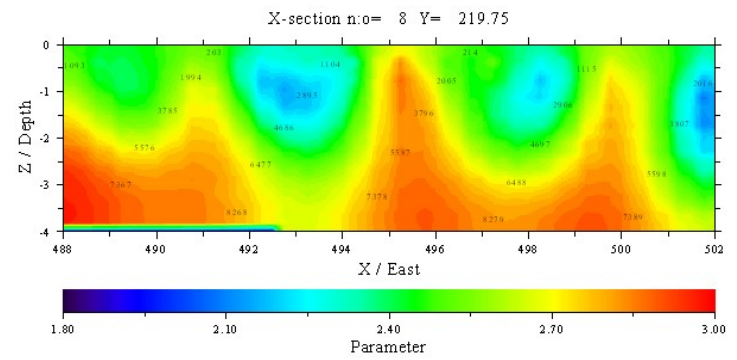

Gambar 4. Penampang model 2D lintasan 2
Penampang model 2D lintasan 3 yang terdapat pada $Y=225,25$ ditunjukkan oleh Gambar 5. Berdasarkan pada peta geologi daerah panas bumi Sipoholon, sayatan penampang ini melintasi Gunung Siborboron, satuan piroklastik Toba 2, satuan endapan aluvium, sinter karbonat, dan juga daerah mata air panas Hutabarat. Anomali maksimal pada sayatan ini bernilai sekitar 7,5 mgal. Kondisi ini dikarenakan oleh adanya massa batuan berdengan densitas tinggi (warna merah) dengan nilai $2,80-3,00 \mathrm{~g} / \mathrm{cm}^{3}$ pada koordinat $X$ antara 488 sampai 490 dan pada kedalaman rata-rata $Z>2 \mathrm{~km}$ pada koordinat $X$ antara 497 sampai 502 dan pada kedalaman $\mathrm{Z}>1,7 \mathrm{~km}$.

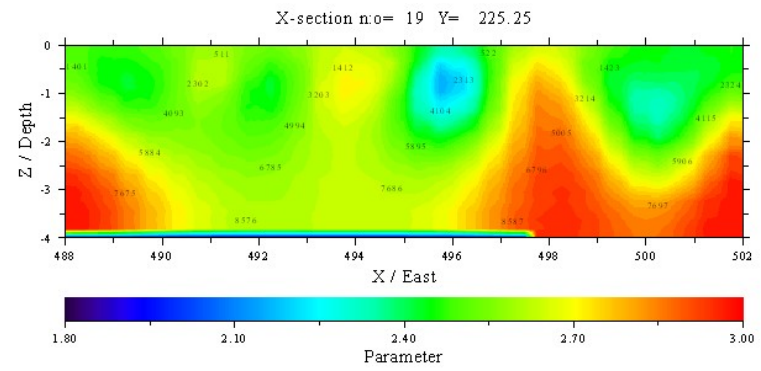

Gambar 5. Penampang model 2D lintasan 3

Penampang model 2D lintasan 4 yang terdapat pada $Y=227,25$ ditunjukkan oleh Gambar 6 . Berdasarkan pada peta geologi daerah panas bumi Sipoholon, sayatan penampang ini melintasi daerah satuan endapan aluvium, satuan piroklastik Toba 2 dan beberapa pa-tahan berarah barat lauttenggara. Anomali gravitasi maksimal pada sayatan ini bernilai sekitar 4 mgal. Kondisi ini dikarenakan oleh adanya massa batuan dengan berdensitas sedang (warna jingga) dengan nilai 2,75 - 2,85 $\mathrm{g} / \mathrm{cm}^{3}$ pada koordinat $X$ antara 495,5 sampai 496,5 dan kedalaman $Z$ antara 0,4 km sampai 1,2 km.

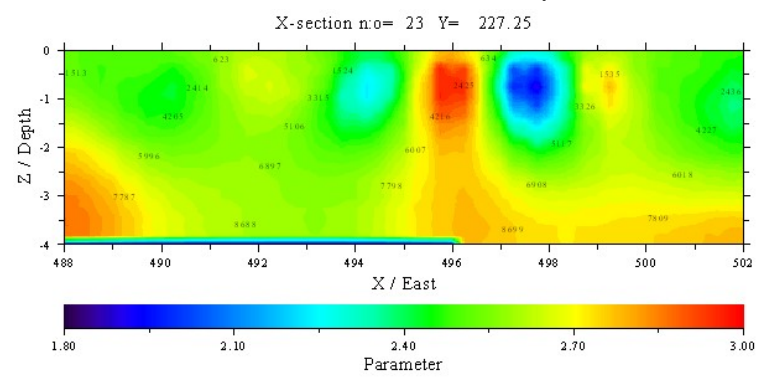

Gambar 6. Penampang model 2D lintasan 4

Penampang model 2D lintasan 5 yang terdapat pada $Y=229,25$ ditunjukkan oleh Gambar 7 . 
Berdasarkan pada peta geologi daerah panas bumi Sipoholon, sayatan penampang ini melintasi daerah Gunung Palangkagading, satuan Piroklastik Toba, sinter karbonat, dan mata air panas Sipoholon. Anomali gravitasi maksimal pada sayatan ini bernilai sekitar 7 mgal. Kondisi ini dikarenakan oleh adanya massa batuan berdensitas sedang (warna jingga) dengan nilai $2,75-2,95 \mathrm{~g} / \mathrm{cm}^{3}$ pada koordinat $X=497$ dan kedalaman $Z=0,5 \mathrm{~km}$.

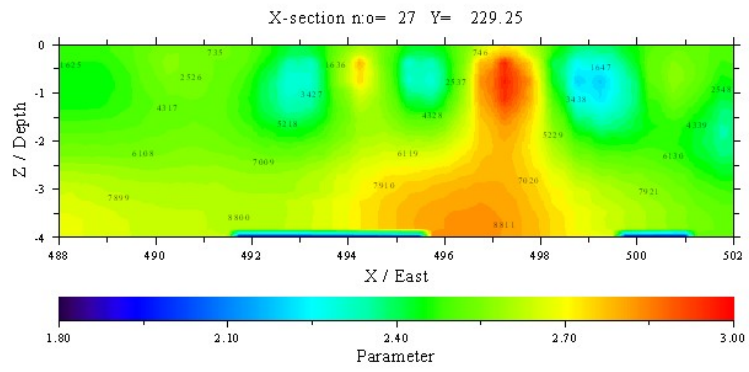

Gambar 7. Penampang model 2D lintasan 5

Penampang model 2D lintasan 6 yang terdapat pada $\mathrm{Y}=230,75$ ditunjukkan oleh Gambar 8. Berdasarkan pada peta geologi daerah panas bumi Sipoholon, sayatan penampang ini melintasi daerah Gunung Palangka Gading dan satuan piroklastik Toba 2. Sayatan ini merupakan sayatan paling utara dari daerah penelitian. Anomali maksimal pada sayatan ini bernilai sekitar 5 mgal. Kondisi ini dikarenakan oleh adanya massa batuan berdensitas tinggi (warna jingga kemerahan) dengan nilai 2,80$3,00 \mathrm{~g} / \mathrm{cm}^{3}$ pada koordinat $X$ antara 492 sampai 499 yang dimulai pada kedalaman $Z>2 \mathrm{~km}$. Diduga batuan ini merupakan batuan beku intrusi yang telah membeku namun masih memiliki sisa panas.

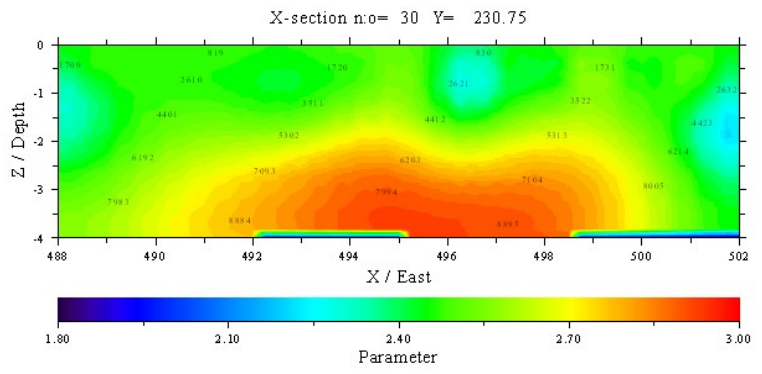

Gambar 8. Penampang model 2D lintasan 6

Hasil pemodelan juga diinterpretasi secara 3D (Gambar 9). Model densitas 3D tersebut menunjukkan batuan dengan densitas tinggi tersebar dan berkelompok-kelompok di beberapa tempat mulai pada kedalaman $>1,5 \mathrm{~km}$. Batuan berdensitas tinggi dengan nilai $2,80-3,00 \mathrm{~g} / \mathrm{cm}^{3} \mathrm{di}$ bagian selatan dan timur terlihat muncul dari bawah hingga hingga kedalaman $2 \mathrm{~km}$. Batuan ini diinterpretasikan sebagai batuan beku intrusif yang diperkirakan berperan sebagai sumber panas pada sistem panas bumi di daerah penelitian ini.

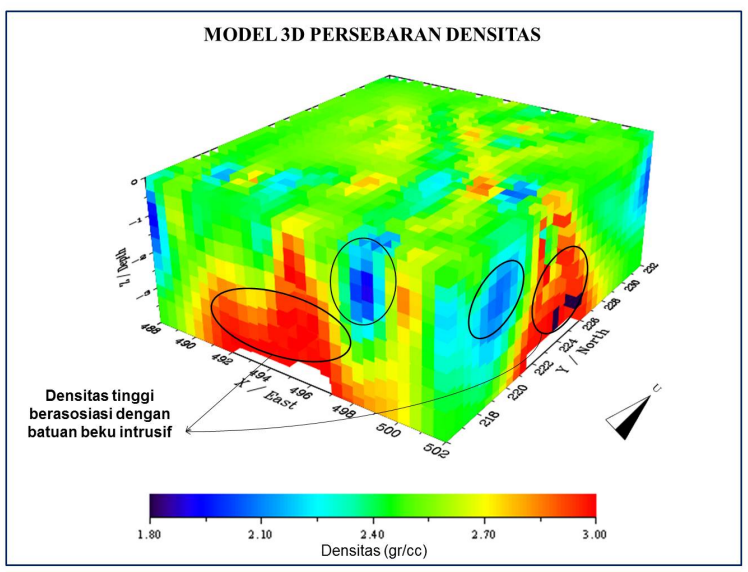

Gambar 9. Interpretasi model densitas 3D

\section{PENUTUP}

\section{Simpulan}

Hasil pemodelan inversi 3D data gaya berat memperlihatkan bahwa adanya blok batuan berdensitas tinggi dengan nilai antara 2,80-3,00 $\mathrm{g} / \mathrm{cm}^{3}$ yang tersebar di selatan dan timur pada kedalaman Z $>2 \mathrm{~km}$. Batuan ini diinterpretasikan sebagai batuan beku intrusif dan diduga berperan sebagai sumber panas dari sistem panas bumi daerah penelitian.

\section{Saran}

Hasil penelitian ini dapat digunakan sebagai informasi awal dalam pembuatan model konseptual daerah penelitian. Perlu adanya penelitian lebih lanjut untuk mengidentifikasi komponen penyusun sistem panas bumi lainnya.

\section{Ucapan Terima Kasih}

Penulis mengucapkan terima kasih yang sebesar-besarnya kepada Pusat Sumber Daya Mineral Batubara dan Panas Bumi, Badan Geologi 
KESDM RI atas dukungan data gaya berat sebagai bahan penulisan artikel ini. Rasa terima kasih juga penulis sampaikan kepada Mbak Fitri Jusmi atas kesediaan waktu diskusi dalam proses pengolahan data.

\section{DAFTAR PUSTAKA}

Atef, H., El-Gawada, A.M.S., Zaherb, M.A., dan Faraga, K.S.I. 2016. The Contribution of Gravity Method in Geothermal Exploration of Southern Part of The Gulf of Suez-Sinai Region, Egypt. NRIAG Journal of Astronomy and Geophysics. Vol. 5 (1). Hal: 173-185

Budiraharjo, S., Utama, W., Warnana, D.D., Darmawan, A., 2017. Analisis Inversi 2D Metode Occam Untuk Memodelkan Resistivitas Bawah Permukaan Data Magnetotellurik. J. Geosaintek 3, 1-12. https://doi.org/10.12962/j25023659.v3i1.2950

Constable, S. C., Parker, R. L., dan Constable, C. G. 1987. Occam's Inversion: A Practical Algorithm for Generating Smooth Models from Electromagnetic Sounding Data. Geophysics. Vol. 52 (3). Hal: 289-300

Djudjun, A. 2005. Penyelidikan Gaya Berat Daerah Panas Bumi Sipoholon-Tarutung Kabupaten Tapanuli Utara Propinsi Sumatera Utara. Pemaparan Hasil Kegiatan Lapangan Subdit Panas Bumi 2005. Bandung: Pusat Sumber Daya Geologi Badan Geologi Kementerian Energi dan Sumber Daya Mineral Republik Indonesia

Grandis, H. 2009. Pengantar Pemodelan Inversi Geofisika. Jakarta: Himpunan Ahli Geofisika Indonesia (HAGI)

Hjelt, S. E. 1992. Pragmatic Inversion of Geophysical Data. Jerman: Springer Verlag

Parttijavri, M. 2004. GRABLOX: Gravity Interpretation and Modelling Software Based on 3D Block Model. User's Guide. Archieve Report, Q16.2/2004/2. Hal. 39. Geological Survey of Finland

Sugianto, A dan Rahadinata, T. 2015. Pemodelan Gaya Berat 3D Daerah Panas Bumi Dolok Morawa, Kabupaten Simalungun, Sumatera Utara. Buletin Sumber Daya Geologi. Vol. 10 (2). Hal: 26-39

Situmorang, T. 2005. Penelitian Geomagnet Daerah Panas Bumi Ria-Ria Sipoholon, Tarutung, Tapanuli Utara. Pemaparan Hasil Kegiatan Lapangan Subdit Panas Bumi 2005. Bandung: Pusat Sumber Daya Geologi Badan Geologi Kementerian Energi dan Sumber Daya Mineral Republik Indonesia
Wijaya, R.A.K., Bahri, A.S., Warnana, D.D.W., Darmawan, A.D., 2016. Inversi 1-D Pada Data Magnetotellurik Di Lapangan $X$ Menggunakan Metode Occam Dan Simulated Annealing. J. Geosaintek 2, 75-80. https://doi.org/10.12962/j25023659.v2i2.1920

Zarkasyi, A., dkk. 2015. Buku Panduan Penelitian Panas Bumi. Bandung: Pusat Sumber Daya Geologi Badan Geologi Kementerian Energi dan Sumber Daya Mineral Republik Indonesia. 